\title{
Critical and alternative approaches to leadership learning and development
}

Management Learning 44 (I) 3-10

(C) The Author(s) 2013

Reprints and permission: sagepub.co.uk/journalsPermissions.nav DOI: I0.1 I77//3505076/2473929 mlq.sagepub.com

\section{Gareth Edwards}

University of the West of England, UK

\section{Carole Elliott}

Durham University, UK

\section{Marian Iszatt-White}

Lancaster University, UK

\section{Doris Schedlitzki}

University of the West of England, UK

\begin{abstract}
This article is the introduction to the special issue on 'Critical and Alternative Approaches to Leadership Learning and Development'. This article reviews the past approaches to researching and theorising about leadership learning and development and proposes a shift towards critical and alternative approaches. This article then describes the various articles in the special issue and how they contribute towards this paradigm shift.
\end{abstract}

\section{Keywords}

Critical management education, leadership development, learning

\section{Introduction}

The initial idea for this special issue originated in the theme and contributions to the second Developing Leadership Capacity Conference (DLCC) held at the Bristol Business School in 2010, the theme of which was critical reflections and practical answers for leadership development and learning. The conference produced some in-depth and critical discussions regarding alternative views of leadership development, with the following year's conference - on the theme of

\section{Corresponding author:}

Gareth Edwards, University of the West of England, Frenchay Campus, Bristol, BSI6 IQY, UK.

Email: gareth3.edwards@uwe.ac.uk 
'Leadership Development and Life Experience: Reflections on Becoming Leaders' - consolidating the emerging idea for this special issue. In this introduction, we seek to briefly review the existing literature on leadership learning and development and outline the predominantly essentialist and normative path that this literature has taken over the last 30 years. In response to this trend, the focus of this special issue is to encourage critical and alternative approaches to leadership learning and development. The articles included in this special issue take the subject area forward in theoretical and empirical terms.

\section{Leadership development and learning: a review of past themes?}

John Burgoyne and Kim Turnbull-James (2001) proposed best practice guidelines for leadership development as a response to the increased interest and activity in this field. They suggested that strategic leadership development must (a) be driven from the top: if the chief executive officer (CEO) is not intimately involved and committed to it, it is not worth starting; (b) support and drive the business: if it is not core to an organisation's strategy, it will not happen and (c) be culturally attuned: it must reflect the culture of the organisation. Although this provides guidance to organisations in navigating a large and competitive area, the extent to which individuals can 'learn' to lead and the impact of leadership development on organisations have remained elusive questions in the literature. Hence, our focus in this special issue is on a more critical appreciation of and alternative approaches to leadership learning and development.

Over the last 20 years, there is evidence of an increased discourse regarding leadership development courses and programmes (Day, 2000; Gill, 2006), which suggests that they are seen as a source of competitive advantage (McCall, 1998; Vicere and Fulmer, 1998) in organisations that have significant financial pay-offs (Collins and Holton, 2004). These programmes therefore are increasingly popular (Cacioppe, 1998) and expensive (Fulmer, 1997). Master of Business Administration (MBA) programmes - and particularly executive MBA programmes - are a significant element within this trend, with such programmes often appearing as a proxy for leadership learning in the literature (e.g. Auken et al., 2005; Baruch and Leeming, 2001). Ironically, the much vaunted demise of the MBA (e.g. Connolly, 2003; Pfeiffer and Fong, 2002) seems to have done little to remedy this potentially lazy thinking, and the idea of intervening to develop leadership ability is now considered to be within the mainstream of academic degrees in modern business schools (Gabriel, 2005; Gill, 2004). Elsewhere, leadership development programmes have a long history in military organisations (e.g. Adair, 2005) and started to gain currency in other forms of organisation around the mid-1970s (Edwards et al., 2002; Van Velsor et al., 2010). These early programmes were ultimately self-developmental in nature and promoted the Maslowvian (Maslow, 1968 ) ideals of self-awareness, self-control and self-realisation or actualisation in conjunction with methodologies of an experiential nature (e.g. Kolb, 1984; Mainemelis et al., 2002) grounded in Learning Styles Theory (e.g. Honey and Mumford, 1989). This appears to have been the norm outside business schools until the 1990s when the transformational leadership concept (e.g. Bass, 1985) started to ingrain itself in the academic as well as the practitioner worlds. With this, we see the development of the 'Full Range Leadership' programme (Avolio, 1999) that promoted the development of transformational leadership skills, sometimes to the detriment of other perspectives and certainly in favour of transactional leadership skills (Edwards and Gill, 2012). In addition to these forms of programme, the psychometric analysis of leadership behaviour has also become the norm in organisations with tools such as the Multifactor Leadership Questionnaire (MLQ) (Bass and Avolio, 1995) and the Transformational Leadership Questionnaire (TLQ) (AlimoMetcalfe and Alban-Metcalfe, 2001). Finally, and most recently, there has been a focus 
on authentic leadership development (Cooper et al., 2005), which suggests a process of ethical awareness alongside leadership development. These essentialist and normative ideals (essentialist in the sense of leadership development being presumed as indispensable by organisations, as noted above, and normative in the sense of being prescriptive regarding what is required across differing contexts) are indicative of leadership development in past years and of the business community's tendency towards what they view as readily practical interventions in preference to a more reflective approach (e.g. Gray, 2007; Smith, 2001). There has also been criticism of these approaches (including activities such as $360^{\circ}$ feedback, coaching, mentoring, networking, job assignments and action learning) of being too individually focused and that there is a need for more socially orientated (see Day, 2000 for further elaboration) and systemic (Collins, 2001; Collins and Holton, 2004) approaches to leadership development. These approaches reflect a focus towards alternative and critical approaches to leadership development and learning.

\section{Alternative and critical approaches to leadership development and learning}

More recent studies of leadership development and learning appear to relate back to its experiential nature (Stead and Elliott, 2009; Waldman et al., 2006) and the development of leadership practice from a relational, social and situated perspective through a process of 'becoming' (Cunliffe, 2009; Kempster and Stewart, 2010; Parker, 2004). This research has also encouraged leadership development practices to become more contextually situated and therefore has built on Burgoyne and Stewart's (1977) work on naturalistic leadership learning and wider notions of situated leadership learning (e.g. Bennis and Thomas, 2002; Janson, 2008; McCall, 2004). Arguably, this trend runs parallel to the recent focus on the need for authenticity in leadership (e.g. Avolio and Gardner, 2005) and the recognition of the need for congruence in and a relational perspective (Cunliffe and Eriksen, 2011) on leadership practice. From the literature on the process of 'becoming' in particular, there appears a need for the leadership development and learning literature to appreciate the aspects of emotion, in particular anxiety and desire in the process of 'becoming' a leader and in 'being' a leader. In addition, it appears that leadership learning and development should reconnect with context (Fairhurst, 2009; Jepson, 2009; Liden and Antonakis, 2009; Osborn et al., 2002; Porter and McLaughlin, 2006) and community (Edwards, 2011) and become inclusive and welcoming of critical and creative views discussed further as follows. Alternative approaches to leadership learning and development therefore suggest a further elaboration on these themes and ultimately furthering knowledge, theory, research and practice through an appreciation of different and innovative approaches.

One area that is being developed as an alternative view and that better appreciates context as well as emotions of becoming and being a leader is the move towards aesthetic and artistic methods of management and leadership learning and development (Gayá Wicks and Rippin, 2010; Hansen and Bathhurst, 2011; Taylor et al., 2002). This use of non-cognitive methods such as art enables participants to access intuitions, feelings, stories, improvisation, experience, imagination, active listening, awareness in the moment, novel words and empathy (Taylor and Ladkin, 2009), which contribute to a wider appreciation of leadership in and of organisations. This is one of the topic areas that we seek to explore in this special issue.

In addition, contemporary developments in leadership theorising have drawn on a variety of theoretical perspectives, including poststructuralist, discursive, critical, aesthetic and feminist perspectives to highlight the significance of identity work and regulation, gender and power within leadership development and practice (Collinson, 2005; Fletcher, 2004; Ford, 2006; Ford et al., 2008; Sinclair, 2005). These more critical perspectives on leadership learning and development 
are the second area we seek to advance within this special issue. Indeed, the work around leadership and identity (Ford, 2010 and Ford et al., 2008) has important implications for leadership learning and development. For example, Jackie Ford and colleagues highlight the performative nature of leadership literature and indeed the leadership learning and development discourse. The dominant writing on leadership and the hype around leadership development in contemporary organisations has an influence on how leadership identities are constructed, this being largely masculine, aggressive and controlling self-reliant 'perfect beings'. Managers are therefore encouraged to 'become' leaders and adopt an identity prescribed by the literature and by leadership development programmes. This emerging critical strand of the leadership literature therefore suggests that leadership development and learning should avoid presenting leadership as a fixed identity or role, instead encouraging an awareness of multiple roles (leader, follower and both). In addition, leadership learning and development should strengthen voices of alternative models to the masculine, aggressive and individualistic one. The articles presented in this special issue move these agendas forward in a meaningful way to provide future research and theory in this area with a platform from which to develop.

\section{Themes of the special issue}

This special issue aims to continue these recent threads with a set of articles that extend perspectives of leadership learning and development towards the critical and alternative approaches. This special issue therefore has within it a selection of articles that explore innovative and alternative approaches and interventions that have not received attention in the mainstream leadership learning and development literature.

As can be seen from the following articles, there is an array of interesting innovative and critical notions that have been discussed and empirically regarded. In article one, for example, Birgit Schyns and colleagues explore the role of implicit leadership theories in the process of leadership and leader development, drawing a distinction between traditional trait and behaviour-based approaches to implicit theories of leadership and more open-ended approaches encompassing relational and emotional elements. By acknowledging the importance of context and the role of followers in leadership/leader development, she seeks to contest the often prescriptive stance of traditional leadership development interventions, which seek to shape would-be leaders to fit a predefined model of what a leader should be (Ford and Harding, 2007), suggesting instead the value to be gained by acknowledging both leader and follower implicit theories of leadership and providing space and resources for participants to explore the implications of theories on both sides for how they want to be as a leader. The article critically explores the findings of a drawing activity with undergraduate, postgraduate and executive students and suggests some interesting insights into the implicit theories at work here - for example, the relative absence of followers from the pictures and the frequent focus on heads rather than whole people as a largely rational view of leadership - as well as the more expected gender and race stereotypes. Schyns concludes by discussing the potential of the drawing exercise for overcoming some of the potential barriers to leadership learning implicit in more traditional methods, together with the implication for the kind of leaders we might want to develop based on the implicit theories that emerged.

In another contribution, Ian Sutherland joins the debate surrounding reflexivity in management development through a consideration of experiential learning as a 'process whereby knowledge is created through the transformation of experience' (Kolb, 1984: 41). The article is in response to the traditionally rational, instrumental and economically dominated approach to management development and contributes to the recently increasing interest in the complex, dynamic, chaotic and 
subjective interactional environments that constitute contemporary organisational contexts and the leadership skills and abilities which these demand. In this context, the advantage of arts-based methodologies is seen as being its ability to leverage aesthetic experiences to generate the nonrational, non-logical capabilities needed to navigate and respond to uncertainty, ambiguity and complexity: to reconfigure themselves in order to see more and see differently. Sutherland uses an inductive, grounded research methodology to analyse descriptive essays written by executive MBA students in response to their experience of a choral conducting masterclass as a route to leadership development. The three-stage model that emerges suggests that such methods afford aesthetic workspaces in which this self-configuration can take place through processes of reflection and aesthetic reflexivity and which generate memories with momentum that remain salient and informative for future professional practice. Through these stages, the learning environment was seen to be purposefully framed, evocatively aestheticized and de-routinized - all of which served to produce a frame changing, memorable learning experience, well beyond what more traditional approaches to leadership development often call forth.

Elisabeth Kelan contributes to the growing literature acknowledging the significance of the visual in management and organisation studies. While Schyns and colleagues ask students to draw a leader, Kelan explores how MBA students position themselves in relation to media images of women business leaders. Using the business school environment to explore how gendered 'becoming' in relation to dress and physical appearance take place, Kelan draws on feminist media studies to highlight ways in which identities are constructed in relation to media images, thus offering an innovative contribution to our understandings of the intersections between gender, management and leadership learning. In conducting videoed interviews with 20 MBA students (10 female and 10 male), representing a range of ethnicities and nationalities, two key themes emerged. The students (a) made judgements on the industry-appropriateness of the women's appearance and (b) a majority of students commented on the relationship between sexual attractiveness and women's professionalism, alluding to what they regarded as the opposition between sexual attraction and being a professional woman. For these MBA students, to become, and to be seen, as a businesswoman therefore requires future women leaders to scrutinise what is deemed appropriate according to their industry and to not appear too glamorous or sexy!

Valerie Stead's article focuses on how six women leaders in a UK university learn to deploy (in) visibility in their negotiation of gendered organisational processes and practices. Starting from a position that conceives leadership learning as a socially situated tacit process, her article seeks to extend and deepen this understanding by introducing the concept of (in)visibility, more commonly encountered in feminist theory and research. As an analytic lens (in)visibility illuminates the variety of ways in which gender is revealed and concealed in organisations, and therefore alerts us to the nuances of women's leadership learning and how they might choose to deploy (in)visibility as a tactical tool. Stead's analysis of the six interviews identified three categories of experience: experiences of 'right' and 'wrong' forms of (in)visibility, experiences of (in)visibility due to stereotypical expectations and experiences of revealing and concealing their learning about (in)visibility. In discussing how the women leaders learn to deploy (in)visibility, Stead's analysis reveals how power relations and gender relations are interwoven. For example, when members of recruitment panels, the women leaders revealed ambivalence about their role and the opportunities presented; they simultaneously presented important learning opportunities, but gendered networks of power could easily exclude women from participation in such processes.

Michael Tomlinson and colleagues take a Bourdieusian approach, drawing particularly on his concepts of symbolic violence and capitals, to an analysis of 'centrally initiated' public service leadership development programmes. Undertaking their research in four English public service 
sector organisations, they draw on data from 121 interviews, including those with senior politicians and central government civil servants, and present a critical analysis of policy leaders' and public service leaders' motivations for and understandings of formal leadership development and its impact. They suggest that in the case of their selected public service organisations, leadership development emanating from central government can be conceived as 'a mechanism for the inculcation and development of the social, symbolic and cultural capitals' associated with the 'cultural logic of leaderism'. For leaders subject to leadership development, this is positioned as being a means through which they can widen their influence within the organisation. This highlights further the extent to which these development programmes 'serve as a means to maintaining domination' of the elite through the collusion of organisational leaders to legitimate 'the reproductive power of those who dominate them'.

An additional article by Ken Parry and Steve Kempster associated with this special issue will be published in a later issue of Management Learning. Parry and Kempster's article attempts to move beyond the mainstream conceptions of charismatic leadership to explore the identity and narrative it takes on in an organisational context. Using aesthetic narrative positivism, it considers the emotions that charismatic leadership generates. Based on data from 98 MBA students and executives, Parry and Kempster conclude that the charismatic leadership narrative is one of an enjoyable and supportive family, which includes a place for discipline and tough love when required. Within this narrative, the charismatic leader is required to take on the role of a respected family member, creating an enjoyable and rewarding work context by being a supportive and caring colleague, but not a friend. Would-be leaders, it is suggested, need to intentionally adopt this archetypal identity as part of their leadership development.

\section{Funding}

The author(s) received no financial support for the research, authorship and/or publication of this article.

\section{References}

Adair J (2005) How to Grow Leaders. London: Kogan Page.

Alimo-Metcalfe B and Alban-Metcalfe RJ (2001) The development of a new transformational leadership questionnaire. Journal of Occupational and Organizational Psychology 74: 1-27.

Auken SV, Wells LG and Chrysler E (2005) The relative value of skill, knowledge and teaching methods in explaining MBA programme return on investment. The Journal of Education for Business 81(1): $41-46$.

Avolio BJ (1999) Full Leadership Development: Building the Vital Forces in Organizations. Thousand Oaks, CA: SAGE.

Avolio BJ and Gardner W (2005) Authentic leadership development: Getting to the root of positive forms of leadership. Leadership Quarterly 16(3): 315-338.

Baruch Y and Leeming A (2001) The added value of MBA studies - Graduates' perceptions. Personnel Review 30(5/6): 589-608.

Bass BM (1985) Leadership and Performance beyond Expectations. New York: The Free Press.

Bass BM and Avolio BJ (1995) MLQ Multifactor Leadership Questionnaire (MLQ FORM 5X-Short). Binghamton, NY: Center for Leadership Studies, Binghamton University.

Bennis WG and Thomas RG (2002) Crucibles of leadership. Harvard Business Review 80(9): 39-46.

Burgoyne JG and Stewart R (1977) Implicit learning theories as determinants of the effect of management development programmes. Personnel Review 6(2): 5-14.

Burgoyne JG and Turnbull-James K (2001) Leadership Development: Best Practice for Organisations, Leadership Development: Best Practice Guide for Organisations. London: Council for Excellence in Management and Leadership. 
Cacioppe R (1998) An integrated model and approach for the design of effective leadership development programs. The Leadership \& Organization Development Journal 19(1): 44-53.

Collins DB (2001) Organisational performance: The future of leadership development programs. Journal of Leadership \& Organizational Studies 7: 43-54.

Collins DB and Holton EF (2004) The effectiveness of managerial leadership development programs: A meta-analysis of studies from 1982 to 2001. Human Resource Development Quarterly 15(2): 217-248.

Collinson D (2005) Dialectics of leadership. Human Relations 58(11): 1419-1442.

Connolly M (2003) The end of the MBA as we know it? Academy of Management Learning \& Education 2(4): $365-370$.

Cooper CD, Scandura TA and Schriesheim CA (2005) Looking forward but learning from our past: Potential challenges to developing authentic leadership theory and authentic leaders. Leadership Quarterly 16: 475-493.

Cunliffe AL (2009) The philosopher leader: On relationalism, ethics and reflexivity - A critical perspective to teaching leadership. Management Learning 40(1): 87-101.

Cunliffe AL and Eriksen M (2011) Relational leadership. Human Relations 64(11): 1425-1449.

Day DV (2000) Leadership development: A review in context. Leadership Quarterly 11(4): 581-613.

Edwards GP (2011) Concepts of community: A framework for contextualising distributed leadership. International Journal of Management Reviews 13(3): 301-312.

Edwards GP and Gill R (2012) Transformational leadership across hierarchical levels in UK manufacturing organizations. The Leadership \& Organization Development Journal 33(1): 25-50.

Edwards GP, Winter PK and Bailey J (2002) Leadership in Management. Ross-on-Wye: The Leadership Trust Foundation.

Fairhurst GT (2009) Considering context in discursive leadership research. Human Relations 62: 1607-1633.

Fletcher JK (2004) The Paradox of Postheroic Leadership: An Essay on Gender, Power and Transformational Change. Leadership Quarterly 14: 647-61.

Ford J (2006) Discourses of leadership: Gender, identity and contradiction in a UK public sector. Leadership 2(1): 77-99.

Ford J (2010) Studying leadership critically: A psychosocial lens on leadership identities. Leadership 6: $47-66$.

Ford J and Harding N (2007) Move over management: We are all leaders now. Management Learning 38(5): 475-493.

Ford J, Harding N and Learmonth M (2008) Leadership as Identity: Constructions and Deconstructions. Basingstoke: Palgrave.

Fulmer RM (1997) The evolving paradigm of leadership development. Organizational Dynamics 25(4): 59-72.

Gabriel Y (2005) MBA and the education of leaders: The new playing fields of Eton? Leadership 1(2): $147-163$.

Gayá Wicks P and Rippin A (2010) Art as experience: An inquiry into art and leadership using dolls and dollmaking. Leadership 6: 259-278.

Gill R (2004) Leadership development in MBA programmes. Business Leadership Review 1(2): 1-4.

Gill R (2006) Theory and Practice of Leadership. London: SAGE.

Gray DE (2007) Facilitating management learning: Developing critical reflection through reflective tools. Management Learning 38(5): 495-517.

Hansen H and Bathhurst R (2011) Aesthetics and leadership. In: Bryman A, Collinson D, Grint K, et al. (eds) The SAGE Handbook of Leadership. London: SAGE, 255-266.

Honey P and Mumford A (1989) Manual of Learning Opportunities. Maidenhead: Honey.

Janson A (2008) Extracting leadership knowledge from formative experiences. Leadership 4(1): 73-94.

Jepson (now Schedlitzki) D (2009) Leadership context: The importance of departments. The Leadership \& Organization Development Journal 30: 36-52.

Kempster S and Stewart J (2010) Becoming a leader: A co-produced autoethnographic exploration of situated learning of leadership practice. Management Learning 41(2): 205-219. 
Kolb DA (1984) Experiential Learning. Englewood Cliffs, NJ: Prentice Hall.

Liden RC and Antonakis J (2009) Considering context in psychological leadership research. Human Relations 62: $1587-1605$.

McCall MW (1998) High Flyers: Developing the Next Generation of Leaders. Boston, MA: Harvard Business School Press.

McCall MW (2004) Leadership development through experience. Academy of Management Executive 18(3): 127-130.

Mainemelis C, Boyatzis RE and Kolb DA (2002) Learning styles and adaptive flexibility: Testing experiential learning theory. Management Learning 33: 5-33.

Maslow AH (1968) Toward a Psychology of Being. New York: Van Nostrand.

Osborn RN, Hunt JG and Jauch LR (2002) Toward a contextual theory of leadership. Leadership Quarterly 13: $797-837$.

Parker M (2004) Becoming manager: Or, the werewolf looks anxiously in the mirror, checking for unusual facial hair. Management Learning 35: 45-59.

Pfeffer J and Fong CT (2002) The end of the business school? Less success than meets the eye. Academy of Management Learning and Education 1(1): 78-95.

Porter LW and McLaughlin GB (2006) Leadership and the organizational context: Like the weather? Leadership Quarterly 17: 559-576.

Sinclair A (2005) Body possibilities in leadership. Leadership 1(4): 387-406.

Smith PAC (2001) Action learning and reflective practice in project environments that are related to leadership development. Management Learning 32(1): 31-48.

Stead V and Elliott C (2009) Women's Leadership. London: Palgrave.

Taylor SS and Ladkin D (2009) Understanding arts-based methods in managerial development. Academy of Management Learning \& Education 8(1): 55-69.

Taylor SS, Fisher D and Dufresne RL (2002) The aesthetics of management storytelling: A key to organisational learning. Management Learning 33: 313-330.

Van Velsor E, McCauley CD and Ruderman MN (2010) The Center for Creative Leadership Handbook of Leadership Development. 3rd edn. San Francisco, CA: Jossey-Bass.

Vicere AA and Fulmer RM (1998) Leadership by Design. Boston, MA: Harvard Business School Press.

Waldman DA, Keller RT and Berson Y (2006) Leadership and organizational learning: A multiple levels perspective. Leadership Quarterly 17(1): 110-111. 